\title{
Director liability in insolvency and its vicinity
}

\author{
Kristin van Zwieten*
}

\begin{abstract}
Under English law, directors' duties change in the vicinity of insolvency so as to require enhanced regard for creditors' interests: the rule in West Mercia Safetywear v Dodd. This rule is conventionally analysed as a constraint on directors deploying assets in risky ventures in insolvency. However, a review of the case law shows that the rule performs a very different function: the regulation of payments to creditors in the leadup to insolvency proceedings. On its own, the rule functions as an alternative to a preference action, providing recourse to the director who authorised the payment, rather than the payee. Combined with accessory liability rules, the rule can also function as a substitute for a preference action, providing a different route to recourse from the payee. The first of these functions, however, raises a serious remedial problem acknowledged by the courts - that appears ripe for consideration at an appellate level.
\end{abstract}

\section{Keywords}

Insolvency law; company law; directors' duties; creditor protection; preferences.

\section{Introduction}

It is well established in English law that the duties owed by a director to a company are altered in insolvency and its vicinity so as to require the director to, at minimum, "have proper regard for" ${ }^{1}$ the interests of creditors. This judicially developed rule, conventionally attributed to the Court of Appeal decision in West Mercia Safetywear $v$ Dodd, ${ }^{2}$ operates by altering the duties that are already owed by the director to the company, rather than by supplying a new duty that is owed directly to creditors. Where the rule applies, the director continues to owe duties to the company, but the content of these duties shifts to become more creditor-oriented. Although there is some uncertainty around when the shift occurs, and exactly what it requires, it is at least clear that where the rule applies, non-compliance amounts to a breach of a duty owed to the company, actionable by the company. ${ }^{3}$

The existing literature on the West Mercia Safetywear rule is relatively uniform on the question of the rationale for such a rule. The rationale advanced is that creditor-oriented

\footnotetext{
* Clifford Chance Associate Professor of Law and Finance, Law Faculty, University of Oxford; Fellow, Harris Manchester College. I gratefully acknowledge feedback from John Armour, Dan Awrey, Paul Davies, Joshua Getzler, Roy Goode, Christopher Hare, Gabriel Moss and Richard Nolan on earlier versions of this paper, and comments from participants at a 2015 insolvency conference in Oxford and a subsequent workshop at Clifford Chance in London. I also thank the reviewers for their helpful suggestions. Correspondence to kristin.van-zwieten@law.ox.ac.uk.

${ }^{1}$ Bilta (UK) Ltd (in liquidation) and ors v Nazir and ors (No 2) [2016] AC 1, [123] per Lords Toulson and Hodge.

${ }^{2}$ (1988) 4 BCC 30.

${ }^{3}$ Yukong Line Ltd of Korea $v$ Rendsburg Investments Corporation of Liberia \& Ors [1998] 1 WLR 294, 312; Lord Mance's judgment in Stone \& Rolls Ltd (in liquidation) v Moore Stephens (a firm) [2009] 1 AC 1391, [238] (dissenting but the scope of West Mercia was not in issue).
} 
duty-shifting rules of this kind may deter directors from deploying assets in 'high-risk, high-reward' projects in insolvency and its vicinity, notwithstanding that these strategies may be favoured by shareholders. ${ }^{45}$ The same rationale has been advanced to explain the wrongful trading rule, ${ }^{6}$ which exposes directors of companies in (insolvent) ${ }^{7}$ liquidation or administration to the risk of personal liability where they knew or ought to have concluded that there was no reasonable prospect of the company avoiding insolvent liquidation or administration, and failed (from then on) to take 'every step with a view to minimising the potential loss to the company's creditors' ${ }^{8}$ The wrongful trading rule is compensatory in nature, and more specifically is concerned with compensation for loss caused to the company by the director's failure to take every relevant step ${ }^{9}$ : 'The purpose is to recoup the loss to the company so as to benefit the creditors as a whole'. ${ }^{10}$ This means that the rule can be used to require a director to compensate a company in liquidation or administration for loss flowing from the deployment of assets in a risky venture. The West Mercia rule could undoubtedly be applied to the same end, ${ }^{11}$ with the result that both rules could be understood to perform a similar function.

The impetus for this paper is a series of first instance decisions in which the West Mercia rule has been applied in the English courts, ${ }^{12}$ along with a high profile Australian appellate decision in which the Australian corollary was applied. ${ }^{13}$ The striking feature of these cases is that they all involve the application of the rule to a quite different form of behaviour to that focused on in the West Mercia literature. In

\footnotetext{
${ }^{4}$ i.e. asset substitution: William B. Bratton, 'Bond Covenants and Creditor Protection: Economics and Law, Theory and Practice, Substance and Process’ (2006) 7(1) EBOR 39, section 2.3.

5 See Section 3 below.

${ }^{6}$ See for example Horst Eidenmüller, 'Trading in Times of Crisis: Formal Insolvency Proceedings, Workouts and the Incentives for Shareholders / Managers’ (2006) 7 EBOR 239; Paul Davies, 'Directors' Creditor-Regarding Duties in Respect of Trading Decisions Taken in the Vicinity of Insolvency' (2006) 7 EBOR 301; Rizwaan J. Mokal, 'An Agency Cost Analysis of the Wrongful Trading Provisions: Redistribution, Perverse Incentives and the Creditors’ Bargain’ (2000) 59(2) CLJ 335.

${ }^{7}$ See below $n 57$.

${ }^{8}$ Insolvency Act 1986 ss 214 (liquidation) and 246ZB (administration).

${ }^{9}$ Grant v Ralls [2016] BCC 293, following Re Purpoint Ltd [1991] BCC 121 and In re Continental Assurance Co of London plc; Singer v Beckett [2007] 2 BCLC 287; see also Brooks v Armstrong [2017] BCC 99, [120].

${ }^{10}$ Re Purpoint ibid 129, cited in Grant v Ralls ibid [237].

${ }^{11}$ One formal difference between the West Mercia rule and the wrongful trading rule is that there is no requirement for the company to be in liquidation or administration before a breach of West Mercia affected duty can be pursued. In practice, however, such a breach is most likely to be pursued in the context of insolvency proceedings, and particularly where assets are not expected to be sufficient to discharge creditor claims. In liquidation, s.212 empowers the liquidator or (with leave of the court) a creditor to bring the action on behalf of the company; in administration, the administrator can do so (Insolvency Act 1986 Sch. 1 para. 5). Except as provided for in s.212, creditors do not have standing to litigate a breach of West Mercia Safetywear affected duty: Ross Grantham, 'The judicial extension of directors' duties to creditors' (1991) 1 JBL 1, 17; Yukong (n 3) 312; Paul Davies and Sarah Worthington, Gower: Principles of Modern Company Law (Sweet \& Maxwell, 10 ${ }^{\text {th }}$ ed) [9-15]; Bilta $v$ Nazir (n 1) [125]-[127].

${ }^{12}$ Re Cityspan Ltd [2008] BCC 60; Re HLC Environmental Projects Ltd [2014] BCC 337; Re Micra Contracts Ltd (in liquidation) [2016] BCC 153; Re Cosy Seal Insulation Ltd (in administration) [2016] 2 BCLC 319.

${ }^{13}$ Westpac Banking Corporation v Bell Group Limited (in liq) (No 3) [2012] WASCA 157; (2012) 89 ACSR 1 on appeal from The Bell Group Ltd (in liq) v Westpac Banking Corporation (No 9) [2008] WASC 239; (2008) 70 ACSR 1.
} 
particular, they are all cases in which the rule was applied to produce a remedy where the conduct complained of was a decision of directors to authorise payment out of company assets (or, in the Australian case, the grant of security over company assets) to discharge (or secure) a debt owed to a creditor of the company. The wrongful trading rule provides no remedy for creditors aggrieved by such conduct, for payments to creditors cause no loss to the company: ${ }^{14}$ where assets are used to discharge a genuine debt, the diminution in assets is matched by a diminution in liabilities. ${ }^{15}$ There is however another route to a remedy: the payment (or grant of security) may be vulnerable to avoidance under s 239 of the Insolvency Act 1986 as a preference, such that the court can be asked for an order to restore the position to what it would have been if the payment (or grant) had not been made. ${ }^{16}$

In the English cases reported below, the payments do appear to have been susceptible to adjustment as preferences. Rather than rely exclusively (or in some cases, at all) on section 239, however, the office-holders pursued another route to a remedy: an action against the directors who authorised the payment, on the basis that the authorisation had been given in breach of the duties they owed the company, as affected by West Mercia. This strategy was successful; in each case the directors were found personally liable (either individually, or where a s 239 action was also brought, jointly with the payee) to pay to the company that which had been paid out to the creditor. In the Australian case, the impugned transactions could not be attacked using the Australian preference rule, ${ }^{17}$ although they had the effect of improving the position of one group of unsecured creditors at the expense of others. In response, the liquidators deployed a two-pronged strategy: they alleged breaches of duty by the directors who authorised the transactions, and that the recipient creditors were personally liable as accessories to the breach. This strategy was successful.

Taken together, these cases demonstrate the ability of the West Mercia rule to function (i) as an alternative to a preference action, by providing recourse against the director who authorised the preference (rather than the payee), and (ii) as a substitute for a preference action, by providing (when combined with accessory liability rules) a different route to a remedy against the payee. The role of West Mercia in regulating payments to creditors is yet to be fully explored in the literature, ${ }^{18}$ perhaps because some of the cases are recent, or perhaps because the literature has generally positioned the rule as concerned with a different kind of problem - the deployment of assets in

\footnotetext{
${ }^{14}$ Directors may act in breach of the wrongful trading rule by favouring some creditors over others, but will not be obliged to make a contribution to the company except to the extent that their conduct caused loss to the company: Grant v Ralls (n 9) [244]-[251].

${ }^{15}$ Nor would the common law anti-deprivation and pari passu rules typically offer relief in this context. Those rules target contracts that provide for the company to be deprived of property by reason of its entry into insolvency proceedings, or contracts that would - if binding on a company in insolvency proceedings - have the effect of distributing company property other than in accordance with the statutory distribution scheme (Belmont Park Investments Pty Ltd v BNY Corporate Trustee Services Ltd [2012] 1 A.C. 383). The West Mercia cases reviewed here concern the decision of company directors to improve (by a payment, or the grant of a security interest) the position of some unsecured creditors relative to others in anticipation of the commencement of insolvency proceedings; they are not concerned with the enforceability of contracts that purport to commit the company to improving the position of select creditors in the later event of such proceedings.

${ }^{16}$ See below, text to $\mathrm{n} 74$.

${ }^{17}$ See below, text to $\mathrm{n} 159$.

${ }^{18}$ This is not to say that it has attracted no consideration at all: see the literature noted at the end of n 43 and nn 52-53 below.
} 
risky ventures in insolvency. One consequence of this is that a serious remedial difficulty raised by the use of West Mercia as an alternative to a preference action (the first of the two identified functions) has not yet been properly scrutinised. Recent case law confirms that this difficulty has been acknowledged, but not yet resolved, by the courts. ${ }^{19}$

Section 2 introduces West Mercia Safetywear and the rule attributed to it. Section 3 reviews the literature on the rationale for such a rule. Section 4 turns to the English cases in which West Mercia has been invoked and applied, reporting particularly on the use of the rule in cases where some creditors are aggrieved by a director's decision to authorise payment to other creditors in the lead-up to insolvency proceedings. A remedial difficulty arising from this application of West Mercia is discussed. Section 5 turns to the decision of the Western Australian Supreme Court in Westpac v Bell to demonstrate the potential reach of West Mercia when combined with accessory liability rules, an application which raises no similar remedial difficulty.

\section{The West Mercia Safetywear v Dodd Rule}

The English duty-shifting rule is conventionally attributed to the 1987 decision in Liquidator of West Mercia Safetywear Ltd $v$ Dodd. ${ }^{20}$ In issue in the case was the decision of a director of an insolvent company, Mr Dodd, to authorise the payment of a debt the company owed to its insolvent parent company. A $£ 4,000$ payment was made into the overdrawn bank account of the parent, resulting in a partial discharge of the debt owed by the parent to its bank. The director of the subsidiary was also a director of the parent, and had guaranteed the debt owed by the parent to the bank; the motivation was to reduce the director's liability as guarantor of the parent's bank debt. ${ }^{21}$ Both companies were placed into liquidation, and the liquidator of the subsidiary sought a declaration that the director was "guilty of misfeasance and breach of trust" in arranging the payment, and an order that he repay to the subsidiary the amount it had paid out to the parent. At first instance a County Court judge rejected the liquidator's action, reasoning that the payment had discharged a debt owed by the subsidiary to the parent. Although such an action amounted to the giving of a preference by the subsidiary to the parent, there was no breach of duty by the director in authorising it:

The judge... felt that, although Mr Dodd had acted improperly, he had not misapplied any assets of the [subsidiary] company because he had used the assets merely to pay in part a debt owed by the [subsidiary] company to the [parent] company. ${ }^{22}$

The decision was overturned on appeal, Dillon LJ giving reasons for the court. Dillon LJ found that Mr Dodd had breached a fiduciary duty owed to the subsidiary in arranging the (preferential) payment for his own benefit in circumstances where the subsidiary was already insolvent to the knowledge of its directors. ${ }^{23}$ In explaining the

\footnotetext{
${ }^{19}$ See Northampton Borough Council v Cardoza [2017] EWHC 504 (Ch), [27]-[32], Newey J suggesting (at [32]), in the context of an application for summary judgment, a range of possibilities for reconciling GHLM Trading Ltd v Maroo [2012] 2 BCLC 369 and HLC Environmental Projects (n 12), both discussed below, text to n 127 and n 132 .

${ }^{20}$ (1988) 4 BCC 30.

21 ibid 32.

22 ibid 32.

${ }^{23}$ ibid 33.
} 
significance of the company's insolvency, the judge approved the following extract from Street CJ's judgment in the Australian decision in Kinsela $v$ Kinsela ${ }^{24}$ :

In a solvent company the proprietary interests of the shareholders entitle them as a general body to be regarded as the company when questions of the duty of directors arise. If, as a general body, they authorise or ratify a particular action of the directors, there can be no challenge to the validity of what the directors have done. But where a company is insolvent the interests of the creditors intrude. They become prospectively entitled, through the mechanism of liquidation, to displace the power of the shareholders and directors to deal with the company's assets. It is in a practical sense their assets and not the shareholders' assets that, through the medium of the company, are under the management of the directors pending either liquidation, return to solvency, or the imposition of some alternative administration. ${ }^{25}$

The Court of Appeal declared the director to have been in breach of duty when "for his own purposes, he caused the $£ 4,000$ to be transferred in disregard of the interests of the general creditors of this insolvent company", and ordered him to repay the amount paid. ${ }^{26}$

Although West Mercia attracted immediate academic attention, ${ }^{27}$ there was little judicial analysis of the decision for the first decade or so after it was handed down. The two reported cases of this period that discussed West Mercia in any detail treated it as authority for the proposition that insolvency produced a change in the duties owed by directors to the company, although it is not entirely clear from the reasoning whether the rule was regarded as supplying a new duty (owed to the company) to have regard to creditor interests, or as adjusting one or more of directors' existing duties (owed to the company) so that conformity with these would require regard for creditors' interests. ${ }^{28}$ There is however a larger amount of more recent authority and this has taken the latter approach, treating the rule as one that intrudes into existing duties owed to the company. ${ }^{29}$ Although much of the focus has been on the impact of West Mercia on the duty to act bona fide and in the interests of the company (now encapsulated in s.172 of the Companies Act 2006, which expressly preserves the operation of the West Mercia rule), ${ }^{30}$ it is clear that the shift affects not only this duty, but also others - both of loyalty, and of care. ${ }^{31}$ Additionally, the cases confirm that

\footnotetext{
${ }^{24}$ [1986] 4 NSWLR 722.

${ }^{25}$ Extracted in West Mercia (n 20) at 33.

${ }^{26}$ Subject to a proviso discussed below, text to $\mathrm{n} 80$.

${ }^{27}$ See e.g. D.D. Prentice, 'Creditors’ Interests and Directors’ Duties’ (1990) 10 OJLS 265, Section 4.

${ }^{28}$ See Berg Sons \& Co Ltd v Adams [1992] BCC 661, 679; Facia Footwear Ltd (in administration) $v$ Hinchliffe [1998] 1 BCLC 218, 228.

${ }^{29}$ See for example Re MDA Investment Management Ltd; Whalley v Doney [2005] BCC 783, [70]-[71], [75]; Re Oxford Pharmaceuticals Ltd, Wilson v Masters International Ltd [2010] BCC 834, [92]; Roberts v Frohlich [2012] BCC 407; GHLM Trading Limited v Maroo (n 19) [162]-[166], [168]; Re HLC Environmental Projects Ltd (n 12) [87]-[88]; Vivendi SA v Richards [2013] BCC 771, [146][148]; Bilta v Nazir (n 1) [126] per Lords Toulson and Hodge; $c f$ Lord Mance’s dissenting judgment in Stone \& Rolls Ltd (n 3) [238].

${ }^{30}$ Companies Act 2006 s 172(3), which provides that the duty imposed by s.172 "has effect subject to any enactment or rule of law requiring directors, in certain circumstances, to consider or act in the interests of creditors of the company”.

${ }^{31}$ See for example Roberts v Frohlich (n 29) [83]-[85], [98]; Re MDA Investment Management (n 29)

[70]-[71], [75]; Re HLC Environmental Projects Ltd (n 12) [99].
} 
the duty-shifting rule is complemented by a restriction on shareholders' ability to authorise or ratify a breach of duty when West Mercia is engaged. ${ }^{32}$

Although recent case law has clarified some of the contours of the West Mercia rule, there are at least three aspects of it that remain unclear. ${ }^{33}$ The first is the trigger for its operation, with a range of formulations appearing in the cases. It is clear that the rule can apply before actual insolvency (in Bilta $v$ Nazir, the shift was described as occurring when a company is "insolvent or bordering on insolvency"), ${ }^{34}$ but precisely when it will do so is less clear. ${ }^{35}$ Also uncertain is the precise effect that the rule, once engaged, has on the duties that it affects. In relation to the duty to act bona fide in the interests of the company, for example, some cases suggest that the rule requires exclusive focus on creditors' interests, ${ }^{36}$ or to require such interests to be treated as "paramount". ${ }^{37}$ But other cases do not go so far, instead positing that directors must only take creditors' interests into account, perhaps alongside shareholder interests (on the assumption that these interests diverge). ${ }^{38} 39$ A third area of ambiguity is as to what is meant by "the interests of creditors" when creditors are likely to be heterogeneous in both rights and interests. ${ }^{40}$ The cases require directors to have regard to creditors

\footnotetext{
${ }^{32}$ Re Westminster Property Management Ltd (No. 3) [2004] BCC 581, [32]; Bowthorpe Holdings Ltd v Hills [2003] 1 BCLC 226, [48]-[52]; Lexi Holdings Plc (in administration) v Luqman [2007] EWHC 2652 (Ch), [191]; Madoff Securities International Ltd v Raven [2011] EWHC 3102 (Ch), [97]-[102]; Goldtrail Travel Limited (in liquidation) v Aydin [2015] 1 BCLC 89, [113]-[115] (these holdings not contested on appeal: [2016] BCC 707, [18]); Bilta v Nazir (n 1) [38]; Singularis Holdings Ltd v Daiwa Capital Markets [2017] Bus LR 1386, [129]-[130]; Gower (n 11) [9-15].

${ }^{33}$ All are identified in existing literature, see e.g. Andrew Keay, 'Formulating a Framework for Directors’ Duties to Creditors: An Entity Maximisation Approach’ (2005) 64(3) CLJ 614; AR Keay, 'Directors' duties and creditors’ interests' (2014) 130 (July) LQR 443.

${ }^{34}$ Note 1 at [123] per Lords Toulson and Hodge. Their description of the rule was endorsed by Lord Neuberger, with whom Lords Clarke and Carnwath agreed ([18]-[20]).

${ }^{35}$ In HLC Environmental Projects (n 12) the judge suggested there was 'no difference in principle' in the various formulations in the cases, and that the 'underlying principle' was 'that directors are not free to take action which puts at real (as opposed to remote) risk the creditors' prospects of being paid, without having first considered their interests...' ([89]). But this formulation met with disapproval in BTI 2014 LLC v Sequana SA [2017] Bus LR 82, [477].

${ }^{36}$ See for example Miller v Bain [2002] 1 BCLC 266, [67]-[68] and [72].

${ }^{37}$ Colin Gwyer \& Associates Ltd v London Wharf [2003] BCC 885: "Where a company is insolvent or of doubtful solvency or on the verge of insolvency and it is the creditors' money which is at risk the directors... must consider the interests of the creditors as paramount...” ([74]); Re Idessa (UK) Ltd (in liquidation) [2012] BCC 315, [54]; HLC Environmental Projects (n 12) [92]; Re Micra Contracts (n 12) [23]; Hedger v Adams [2016] BCC 390, [35].

${ }^{38}$ GHLM Trading Limited v Maroo (n 19) [164] and to same effect (from the same judge) Vivendi SA v Richards (n 29) [148]; Re MDA Investment Management Ltd (n 29) [70] and to same effect Ultraframe [2006] FSR 17, [2005] EWHC 1638 (Ch), [1304]; Goldtrail (n 32) [115]: “once the company becomes insolvent, the director no longer owes duties solely to the shareholder but also to the creditors"; Bilta $v$ Nazir (n 1) [123], [126] per Lords Toulson and Hodge.

39 This difference does not simply reflect differences in the formulation of the rule's trigger: some judges identify creditor interests as paramount not only in insolvency but also its vicinity (see e.g. the Colin Gwyer formulation in n 37), a point also made by Keay (n 33) LQR 454-455; other judges require creditor interests to be considered alongside shareholder interests in both insolvency and its vicinity (see e.g. the Goldtrail formulation in $n$ 38).

40 See further Keay (n 33) CLJ 629-633; Henry T.C. Hu and Jay Lawrence Westbrook, 'Abolition of the Corporate Duty to Creditors’ (2007) 107(6) Columbia Law Review 1321, 1352-1353; Keay (n 33) LQR 466-471, grappling with what it means to consider the interests of creditors "as a class” in the context of payments being made to some creditors ahead of others, the subject of Section 4 below.
} 
"as a whole" ${ }^{41}$ or "as a class", ${ }^{42}$ but it is not obvious how directors should proceed where creditors can be predicted to disagree over how assets should be deployed.

\section{The Conventional Account of the Rationale for Duty-shifting in English Law}

One feature of the West Mercia literature is that it offers a fairly uniform account of the rationale for a duty-shifting rule, grounded in a perceived conflict between the incentives of shareholders and the interests of creditors in the zone of insolvency. ${ }^{43}$ In insolvency and its vicinity, shareholders are predicted to favour the pursuit of risky investment projects by the company. Shareholders with knowledge of the company's distress will anticipate its entry into an insolvency procedure, in which shareholders can expect little or no return on their investment - assets likely to be marshalled first in satisfaction of creditors' claims. ${ }^{44}$ In these circumstances, shareholders may be inclined to favour the deployment of assets in 'high-risk, high-reward' projects, the success of which could restore the company to solvency. The 'downside' risk of such projects (the risk of failure) would be borne by creditors - those with a present economic interest in the firm's assets - rather than by shareholders, who have little or nothing left to lose. This model is premised on the liability of shareholders being limited to the amount of unpaid-up capital - it is this that shields them from downside risk. ${ }^{45}$

The West Mercia doctrine relates to the personal liability of directors, not shareholders: so how does the conventional account, which is focused on the incentives of shareholders, explain the targeting of directors? The primary explanation proffered is that, in the absence of a duty-shifting doctrine, directors' interests would otherwise be aligned with shareholders': that is, they would otherwise be inclined to give effect to shareholder preferences, which in the zone of insolvency are said to include a preference for risky ventures. Such an alignment could exist because there is no separation of ownership and control, as where managers are shareholders. ${ }^{46}$ This

\footnotetext{
${ }^{41}$ Ultraframe (n 38) [1304]; Miller v Bain (n 36) [72]; Re Micra Contracts Ltd (n 12) [82].

${ }^{42}$ GHLM Trading Ltd v Maroo (n 19) [168]; Capital for Enterprise Fund a LP v Bibby Financial Services Ltd [2015] EWHC 2593 (Ch), [90].

${ }^{43}$ See e.g. Prentice, 'Creditors’ Interests and Directors’ Duties’ (n 27); Ross B. Grantham, ‘The judicial extension of directors' duties to creditors' (1991) JBL 1; Dan Prentice, 'Corporate Personality, Limited Liability and the Protection of Creditors' in Ross Grantham and Charles Rickett, Corporate Personality in the $20^{\text {th }}$ Century (Hart, 1998) Ch 6; A. Keay 'Directors' Duties to Creditors: Contractarian Concerns Relating to Efficiency and Over-Protection of Creditors’ (2003) 66(5) MLR 665, 668-669; A. Keay, 'Formulating a Framework for Directors' Duties to Creditors: An Entity Maximisation Approach; (2005) 64(3) CLJ 614, esp. 620-624; A. Keay, Company Directors' Responsibilities to Creditors (Routledge 2006), Ch 12; Davies, 'Directors’ Creditor-Regarding Duties' (n 6); Keay LQR (n 33); see also Hu and Westbrook (n 40) 1338 and 1341, noting that the same theme has dominated the literature on the Delaware duty-shifting rule. Thomas Bachner's Creditor Protection in Private Companies (CUP 2009) is an exception to the English trend: it identifies multiple roles for the West Mercia rule, including the regulation of payments to creditors (239-240), although the text is concerned primarily with shareholder-creditor conflicts in closely held firms, and therefore focuses particularly on the risk of preferential payments to owner-managers (21-22).

${ }^{44}$ Philip R Wood, Principles of International Insolvency Law ( $2{ }^{\text {nd }}$ ed, Sweet \& Maxwell, 2007) [11002].

${ }^{45}$ See Davies (n 6) 306; see also Thomas Telfer, 'Risk and Insolvent Trading' in Grantham and Rickett (n 43) 129, and Westpac v Bell (n 13) [770] per Lee AJA. In the UK, s.74(2) of the Insolvency Act 1986 limits shareholders' liability in the winding up of a company limited by shares to the amount, if any, unpaid on their shares.

${ }^{46}$ As Davies has argued, directors who are not shareholders can also come under the influence of a controlling shareholder / director: (n 6) Section 3.2.
} 
analysis makes the closely held corporation the most plausible target of duty-shifting and more specifically the large closely held company, for in smaller firms managerowners may have foregone the benefits of limited liability through the giving of guarantees for company debts. ${ }^{47}$ An alternative analysis is that the posited alignment between managers and shareholders arises by operation of law, through the imposition of ordinary, shareholder-regarding, duties: if, for example, a duty to act "in the interests of the company" was equated with a duty to act to maximise shareholder wealth, ${ }^{48}$ and the latter with high levels of risk-taking in insolvency, ${ }^{49}$ then compliance might be thought to mandate pursuit of high-risk strategies. ${ }^{50}$ On this analysis a duty shift would be necessary to relieve directors of such an obligation. ${ }^{51}$

It is not the case that the literature on West Mercia asserts that the only possible rationale for the rule is to restrict risk-taking in the vicinity of insolvency: some of it acknowledges the possibility that the rule could have a role in constraining other kinds of behaviour in insolvency, ${ }^{52}$ or at least acknowledges that the rule has in fact been invoked in response to other kinds of behaviour. ${ }^{53}$ However alternative accounts of the case for a duty-shifting rule are yet to be fully developed: it is the risk-taking account that has dominated to date. One consequence is that the rule has tended to be analysed alongside a second source of personal liability for directors who are reckless in their management of the firm in insolvency or its vicinity - the wrongful trading rule in ss 214 (liquidation) and 246ZB ${ }^{54}$ (administration) of the Insolvency Act 1986.

The wrongful trading rule was proposed in 1982 by the Cork Committee in response to a perceived gap in personal liability rules for directors who acted honestly, but recklessly or unreasonably, in the firm's insolvency. ${ }^{55}$ Although the Committee's draft rule focused on directors who caused the firm to incur new liabilities when there was no reasonable prospect of their repayment, ${ }^{56}$ the rule eventually enacted was broader. The rule exposes directors of companies in (balance-sheet insolvent) ${ }^{57}$ liquidation or administration to the risk of personal liability where they knew or ought to have concluded that there was no reasonable prospect of the company avoiding insolvent liquidation/administration, and failed (from then on) to take "every step with a view to

\footnotetext{
${ }^{47}$ For some early evidence, see Judith Freedman and M. Godwin, 'Incorporating the micro business: perceptions and misperceptions’ in Alan Hughes and D.J. Storey (eds) Finance and the Small Firm (Routledge, 1994) 246.

${ }^{48}$ For a critique of the value of equating these, see Douglas G. Baird and M. Todd Henderson, 'Other Peoples’ Money’ (2008) 60(5) Stanford Law Review 1309.

49 This assumes the adoption of a purely ex post perspective: see T.A. Smith, 'The Efficient Norm for Corporate Law: A Neotraditional Interpretation of Fiduciary Duty’ (1999) 98(1) Michigan Law Review 214.

50 This argument appears to be implicit in Davies’ analysis (n 6, Section 2.2) and has been explicitly developed by Keay: CLJ (n 33) 620; see also from a US perspective, Baird and Henderson (n 48) 13121313.

${ }^{51}$ Baird and Henderson (n 48) 1320.

52 See for example Davies (n 6) 303, referring to asset siphoning; Bachner (n 43) 22 referring to asset siphoning and preferential payments to insider (owner-manager) creditors in closely held firms.

${ }^{53}$ See Keay (n 33) LQR section III(c) and A. Keay, 'Challenging Payments made by Insolvent or Near Insolvent Companies’ (2015) 3 NIBLeJ 11, both discussing the application of West Mercia in some cases involving payments to creditors, the latter drawing on the former.

54 This provision was inserted by the Small Business, Enterprise and Employment Act 2015 s 117.

${ }^{55}$ Insolvency Law and Practice: Report of the Review Committee (1982; Cmmd. 8558), [1782].

56 ibid [1781].

${ }^{57}$ That is, the company's assets are insufficient for the payment of its debts and the expenses of the liquidation or administration: Insolvency Act 1986 ss 214(6), 246ZB(6).
} 
minimising the potential loss to the company's creditors as... [they] ought to have taken". Such a rule could clearly attack the deployment of assets in risky ventures that do not pay off, and the remedy under ss 214/246ZB would have the broad effect of restoring creditors to the 'pre-gamble' position: the remedy is compensatory (more specifically, directors are asked to make a contribution to the company for loss caused to it by the breach), ${ }^{58}$ and the starting point for determining quantum is the difference between the net estate as at the point when directors knew or ought to have concluded that there was no reasonable prospect of avoiding insolvent liquidation/administration, and the net estate on commencement of the proceedings. ${ }^{59}$ On this analysis, West Mercia appears to cover some of the same ground as the wrongful trading rule, but is capable of being triggered earlier (the wrongful trading rule is engaged only where directors have the requisite knowledge of there being no reasonable prospect of avoiding insolvent liquidation/administration, while West Mercia is engaged by mere insolvency or approaching insolvency). ${ }^{60}$ West Mercia could therefore function as a complementary constraint on the reckless deployment of firm assets in the vicinity of insolvency.

\section{A Review of the English Duty-shifting Cases}

The conventional account of the rationale for the duty-shifting rule posits a conflict between shareholders and creditors over the appropriate level of risk to be taken on by the company in insolvency. It will be immediately obvious that West Mercia Safetywear did not concern such a conflict. West Mercia is not a case about the reckless 'gambling' of assets in some risky venture that did not pay off, leaving creditors to look to a diminished estate for satisfaction. Rather, the conduct complained of was the discharge of a debt - payment to one unsecured creditor while others were left to prove for a pro rata distribution in the liquidation that followed. What about the cases that have been handed down since?

A review of the cases reveals few examples of West Mercia being invoked in response to the kind of recklessness anticipated in the literature. ${ }^{61}$ Of course, the fact that West Mercia does not appear to have been invoked in response to reckless 'gambles' in insolvency does not mean that the rule has no impact on incentives to engage in such behaviour: "the level of reported cases and the impact of any particular law is complex and not by any means unilinear". ${ }^{62}$ Of greater significance for present purposes, however, is the fact that the case law reveals the application of the rule to two quite different forms of behaviour to that focused on in the conventional account of the rule.

The first kind of 'problem behaviour' by directors that appears in the cases is the gifting of company assets (or their transfer at undervalue) in insolvency or its vicinity, so as to confer some benefit on directors or their associates. One case involved the sale of a company's business on terms that a substantial proportion of the purchase price would be paid to a related entity (a partnership in which the controlling director of the

\footnotetext{
${ }^{58}$ See the authorities cited in $\mathrm{n} 9$ above.

${ }^{59}$ Grant v Ralls (n 9) [236]-[241], reviewing the authorities; Brooks v Armstrong (n 9) [120].

${ }^{60}$ A point made by Davies (n 6) 329.

${ }^{61}$ The closest the authorities get to this kind of behavior is probably the "blind optimism" of the directors in Roberts $v$ Frohlich (n 29), but even this case did not involve any change in the riskiness of the firm's investments in the vicinity of insolvency: the venture was "speculative” from the outset: [4].

62 Davies (n 6) 325.
} 
company had the majority stake), ${ }^{63}$ in circumstances where the company was either already insolvent or in a "dangerous financial position", and the company's controlling shareholder-director appears to have been attempting to avoid the application of the sale proceeds to creditor claims. ${ }^{64}$ The company was later wound up, and the liquidator brought an action against the director alleging that the structuring of the transaction so that the consideration was paid to a related entity had constituted a breach of fiduciary duty by the director, and seeking an order that the director compensate the company by repaying that which was paid to the related entity. The judge made the order, ${ }^{65}$ finding that the director had acted in breach of the duties he owed the company - as affected by West Mercia ${ }^{66}$ - in arranging for part of the consideration to be paid over to the related entity. ${ }^{67}$ Yukong Lines Ltd of Korea $v$ Rendsburg Investments Corporation of Liberia $^{68}$ involved similar behaviour: there a shadow director arranged the transfer of assets from the company to another entity that he or his family controlled, so as to avoid creditor attachment. The case was not a directors' duty case, but in the course of his judgment Toulson J observed:

$\mathrm{Mr}$ Yamvrias undoubtedly owed a fiduciary duty to [the company]. Although he was not formally a director, he was a "shadow director" and controlled the company's activities. To remove the funds in [the company's] bank account when it had a probable liability to [the creditor] far in excess of its assets involved a clear breach of that fiduciary duty: West Mercia Safetywear... ${ }^{69}$.

There is of course no need to have recourse to West Mercia to establish that a director who siphons off company assets acts in breach of duty, whether the company is solvent or insolvent. ${ }^{70}$ The role played by West Mercia in the insolvency context is to restrain shareholders from authorising the breach ex ante or ratifying it ex post: once the creditor-regarding rule is engaged, shareholders are unable to permit or cleanse the breach. ${ }^{71}$ However, West Mercia will not always be needed to supply this restraint: where the conduct is properly characterised ${ }^{72}$ as an unlawful distribution to shareholders, then there will be no scope for shareholder validation. ${ }^{73}$

West Mercia Safetywear is however central to the second category of case, which involves a quite different form of behaviour. Here, the impugned behaviour is a decision by a director to authorise payment to some of the company's creditors in circumstances where the company was unable to pay all of its debts, and subsequently ended up in an insolvency procedure in which unpaid creditors were left to prove for a pro rata distribution from the assets remaining. This is kind of behaviour that was impugned in West Mercia itself, and a review of the subsequent case law reveals that

\footnotetext{
${ }^{63}$ MDA Investment Management Ltd (n 29).

64 ibid [107]-[108].

${ }^{65}$ MDA Investment Management Ltd (No 2) [2004] EWHC 42 (Ch), also reported in [2005] BCC 783.

${ }^{66}$ Note 29 at [75], [105], [108].

${ }^{67}$ See also Inland Revenue Commissioners v Richmond [2003] 2 BCLC 442; Miller v Bain (n 36).

68 [1998] 1 WLR 294.

69 ibid 311.

${ }^{70}$ Re Snelling House Ltd (in liquidation) [2012] EWHC 440 (Ch), [40]-[44].

${ }^{71}$ Text to $\mathrm{n} 32$ above; see also Goldtrail (n 32) [114].

${ }^{72}$ As to which, see Progress Property Co Ltd v Moore [2011] 1 WLR 1.

${ }^{73}$ Aveling Barford Ltd v Perion Ltd (1989) 5 BCC 677; Re Stakefield (Midlands) Ltd [2011] 2 BCLC 541, [41].
} 
similar fact patterns have been litigated on multiple occasions since, sometimes (at least more recently) with the same result.

There is another route to a remedy where a company pays some its creditors in full, and then ends up in an insolvency procedure unable to pay others. Such behaviour is classically dealt with by transaction avoidance law, and specifically by the law of preferences. In English law, section 239 of the Insolvency Act 1986 governs the avoidance of preferences. A preference is defined as doing something ${ }^{74}$ that puts a creditor (or a surety or guarantor of the company's debts) in a position that, in the event of the company's entry into insolvent liquidation, will be better than the position the recipient would have been in had the thing not been done. ${ }^{75}$ There are further criteria that must be established before a preference can be unwound (it must have been made at the "relevant time", defined by reference to both temporal and financial conditions, ${ }^{76}$ and the company must have been influenced by a desire to produce the preferential effect), ${ }^{77}$ but where these are satisfied the liquidator or administrator can apply for an order to restore the position to what it would have been had the company not given the preference. In the paradigm case of the payment of an unsecured debt, the typical order would be for repayment (swelling the assets available for distribution) and the revival of the debt (producing a corresponding increase in the company's liabilities). In other words, the net estate will be unchanged (at least in theory), ${ }^{78}$ but unsecured creditors will expect a better outcome in a pro rata distribution, since the payee will now be forced to participate. ${ }^{79}$

In West Mercia it appears to have been accepted that the payment made to the parent was vulnerable to being unwound as a preference under the precursor to s 239, but no such action was apparently brought. This was presumably because the $£ 4,000$ payment was made by crediting the parent's overdrawn bank account (thus being applied immediately to discharge the parent's debt to the bank), and the parent was insolvent: the company had "no other assets available to repay the $£ 4,000$ ". ${ }^{80}$ Instead, the liquidator took an alternative route to a remedy: rather than look to the parent to repay the subsidiary, the liquidator looked to the director who had (self-interestedly) authorised the payment to do so. The making of such an order would, however, have put the unsecured creditors of the subsidiary in a better position than they would have been in had the parent not been paid: the assets of the subsidiary would be swelled by payment from the director, without any corresponding increase in liabilities (since the debt to the parent would remain discharged). To avoid this result, the Court of Appeal

\footnotetext{
${ }^{74}$ Or suffering something to be done.

${ }^{75}$ Section 239(4).

${ }^{76}$ Section 240. The temporal condition is that the preference occurred 6 months before the "onset of insolvency" (defined by reference to the commencement of insolvency proceedings), or 2 years in the case of connected parties: ss 240(1), (3), 249. The financial condition is that the company was unable to pay its debts (within the meaning of s 123) at the time the preference was given or in consequence of it: s 240(2).

77 See s.239(5) Insolvency Act 1986 and Re MC Bacon Ltd (No 1) [1990] BCC 78. The requisite desire is presumed in relation to connected parties until the contrary is shown: s.239(6).

${ }^{78}$ In practice the company's assets will be diminished by the costs of investigating and bringing the action: Alan Schwartz, ‘A normative theory of business bankruptcy’ (2005) 91 Virginia L. Rev. 1199. ${ }^{79}$ Under English law the fruits of the action are not susceptible to capture through an after-acquired property clause in a security agreement: see Re Yagerphone Ltd [1935] Ch 392. This position has now been codified in s.176ZB of the Insolvency Act 1986, added by s.119 of the Small Business, Enterprise and Employment Act 2015.

${ }^{80}$ (1988) 4 BCC 30, 32.
} 
ordered the director to repay the $£ 4,000$ to the subsidiary (with interest), but also ordered that the remaining debt owed by the subsidiary to the parent be notionally increased by $£ 4,000$ for the purpose of calculating the parent's entitlement to a distribution in the subsidiary's liquidation, with any dividend attributable to the notional increase to be recouped by the director rather than paid to the parent. The overall effect was to produce a similar result for unsecured creditors to that which would have been obtained had the payment been set aside as a preference.

Attempts to apply West Mercia Safetywear to other cases where directors had authorised the payment of debts in insolvency were initially unsuccessful, with judges appearing to favour a narrow reading of West Mercia. In Facia Footwear Ltd (in administration) $v$ Hinchliffe, ${ }^{81}$ a claim by administrators that a director had been guilty of misfeasance in authorising the repayment of a debt owed by the "hopelessly insolvent" company to a related entity was dismissed as untenable by the ViceChancellor given the administrators' failure to attack the payment as a preference: "no point being taken about fraudulent preference, it seems to me impossible to describe the authority given for the payment as misfeasance". ${ }^{82}$ The implication of this is that a finding that the authorisation of the payment constituted a breach of duty would depend on a finding that the payment could be avoided as a preference in the company's administration or liquidation. In Knight $v$ Frost, ${ }^{83}$ handed down the following year, Justice Hart favoured a similar approach. Knight involved a derivative action by a shareholder (who was also a creditor of the company) alleging that the decision of a controlling director-shareholder to authorise the payment of a debt owed by the (then insolvent) company to a related entity (in which the controlling director also had an interest) had been taken in breach of the duties he owed the company. The shareholder relied on West Mercia and Washington Diamond Mining Co ${ }^{84}$ (a case relied on in West Mercia), but Hart J considered these cases distinguishable:

In both the West Mercia Safetywear and Washington Diamond Mining Co cases, the payment in question had been a fraudulent preference because it had been made within the relevant statutory period prior to the commencement of a winding up. They are not authority for the proposition that a director who for his own purposes causes the company to prefer one of its creditors over another outside that statutory period is liable to replace the money at the suit of the company. It is through the mechanism of liquidation that creditors are protected and the plaintiff has in this case chosen to pursue a derivative action as a shareholder rather than to petition, as creditor, for [the company] to be wound up. ${ }^{85}$

The reasoning of Hart $\mathrm{J}$ in Knight $v$ Frost was endorsed soon after by Park J in Singer $v$ Beckett. ${ }^{86}$ In that case, the liquidators argued that payments which amounted to a factual preference ${ }^{87}$ of the recipients but which could not (because of the absence of the

\footnotetext{
${ }^{81}$ [1998] 1 BCLC 218.

82 ibid 229.

83 [1999] BCC 819.

84 [1893] 3 Ch 95. See n 137 below.

${ }^{85}$ Note 83 at 834.

${ }^{86}$ [2007] 2 BCLC 287.

${ }^{87}$ i.e. they did, as a matter of fact, have the effect of putting the recipient in a better position than they would otherwise have been in, had the company immediately entered liquidation: ibid, text to n 75 .
} 
requisite desire) be avoided under s 239 could nevertheless form the basis of a finding of breach of duty by the directors who authorised them at a time when the company was insolvent. The judge held:

It seems to me entirely wrong to use a misfeasance action to get round the liquidators' inability to use section 239. My view on this point is entirely in line with that of Hart $\mathrm{J}$ in Knight $v$ Frost distinguishing the decision of the Court of Appeal in West Mercia Safetywear... . In the West Mercia case the payment which was held to have been an actionable misfeasance had been an unlawful preference within the statutory predecessor of section 239. The payments... in this case were not unlawful preferences within that section, and in agreement with Hart J I do not think that they constituted breaches of duty owed by the directors to [the company]. ${ }^{88}$

In Re Brian D Pierson (Contractors) Ltd, ${ }^{89}$ another decision of the same period, deputy judge Hazel Williamson QC reasoned similarly, appearing to treat a finding of an unlawful preference under s 239 as a prerequisite to a finding that the authorisation of the payment constituted a breach of duty. On the facts, the judge found that the relevant payment ${ }^{90}$ was not susceptible to avoidance under s 239 (again, due to the lack of the requisite desire), such that the allegation of breach in its authorisation could not be made out. She added, however, that even if the requirements of s 239 had been satisfied, this would not necessarily have led her to a finding of breach of duty. She noted that West Mercia had involved the payment of a preference "for the known purpose" of advancing the director's personal interests, and continued:

I do not read West Mercia as saying that in all cases where a preference under s. 239 can be made out, the directors responsible necessarily commit a misfeasance or breach of duty. That would be tantamount to saying that directors simply have a duty not to allow s. 239 to be breached. In my judgment this is too sweeping. It must be a matter of fact, in any particular case, whether the acts of a director which are held to constitute the giving of a preference are also, in their own right, acts which amount to misfeasance and breach of duty. This test will be applied bearing in mind that in the case of imminent liquidation the directors owe duties to creditors as well as shareholders. ${ }^{91}$

These early authorities suggest a cautious approach to the application of West Mercia to cases involving the payment of company debts, with judges appearing anxious to limit the rule's application to cases in which, at minimum, the payment could also be set aside as a preference. ${ }^{92}$ But even on this restrictive approach - indeed, even if West Mercia is confined to cases involving voidable preferences that are authorised by

\footnotetext{
${ }^{88}$ Note 86 at [420].

${ }^{89}$ [1999] BCC 26.

${ }^{90}$ A redundancy payment to the son of the directors.

${ }^{91}$ Note 89 at 46 . This passage was applied in Re Oxford Pharmaceuticals Ltd (n 29), the deputy judge there holding that directors had not acted in breach of duty in authorising what were voidable preferences, despite having benefited from them (as guarantors of the company's debts), on the basis that the liquidator had failed to make out a positive case that "there had been a conscious application of the company's funds for the known purpose of preferring the directors' own interests, or those of their associates": [93].

${ }^{92} C f$ the more flexible approach advocated by Newey J in GHLM Trading Ltd v Maroo (n 19) [168].
} 
directors self-interestedly - there is clearly scope for the rule to play a significant role. Four more recent cases confirm this.

The first of these is Re Cityspan $L t d,{ }^{93}$ in which a liquidator sought an order that one of two directors repay three sums (totalling £33,000) that had been paid out by the company on the authorisation of the two directors in the months leading up to the (insolvent) liquidation. All three payments had been made to discharge loans made to the company by the two directors. Two payments were made to the defendant director himself, to repay loans he had made, and these were successfully challenged as preferences. The third payment was however made to the other director, in discharge of a loan he had made to the company. Rather than challenge the latter payment as a preference in proceedings against the second director, the liquidator sought repayment by the first director on the basis that his authorisation of the payment constituted a breach of the duties he owed the company, as affected by West Mercia. The judge held that the first director was liable to repay all three sums on this basis:

[A]t the time Mr Clark [the director] authorised the three transfers he knew that the company was insolvent and that its creditors would be detrimentally affected by the removal of the sums represented by those transfers. In those circumstances, by the time of the transfers, the fiduciary and common law duties which Mr Clark owed to Cityspan required him to act having regard to and so as to protect the general interests of the company's creditors... In light of those duties, Mr Clark has not sought to suggest that there was any basis on which he could properly have arranged for the payment of the three transfers to [the other director] and himself, and I find that there was none.

I therefore hold that each of the three transfers was authorised by $\mathrm{Mr}$ Clark in breach of both his fiduciary and common law duties, and that he is liable on this basis to [the liquidator] to pay compensation of $£ 33,000 .^{94}$

In the second case, Re HLC Environmental Projects Ltd, ${ }^{95}$ the liquidators sought an order that the controlling director of an English subsidiary of a Portugese company had acted in breach of his duties to the subsidiary when authorising various payments to its creditors - including the director himself; the parent company (which the director also controlled); and the subsidiary's bank, in relation a debt guaranteed by the parent - at a time when the company was insolvent. The liquidators succeeded without making any claim based on s 239: indeed, it appears that s 239 was not pleaded, and a late attempt to amend the pleadings was denied. ${ }^{96}$ The judge found that at the time the payments were made the director's duties had been affected by West Mercia. He held that the payments had been made in breach of the director's duty to act bona fide in the interests of the company, and in breach of his duty to exercise powers for a proper purpose. The director's strategy had been to "reduce the company's indebtedness to associated creditors as and when cash became available to enable that to be done". ${ }^{97}$ The payments had been made to assist the director personally or to assist the parent that he controlled,

\footnotetext{
93 [2008] BCC 60.

94 ibid, 66. Interestingly, the order does not appear to have been made subject to the same proviso that was made in West Mercia, described at text to $\mathrm{n} 80$ above.

95 [2014] BCC 337.

96 ibid [3].

97 [79].
} 
"without giving any consideration to the best interests of the company's creditors as a whole". In making the payments the director had in effect been "choosing which creditors to pay, and which to leave exposed to a real risk of being left unpaid", and no intelligent and honest person in the director's position would have reasonably believed that the payments were made in the best interests of the company or its creditors "as a whole". ${ }^{98}$ The director was ordered to repay the sums paid out, the order being given in the same form as that given in West Mercia.

The third case, Re Micra Contracts Ltd (in liquidation), ${ }^{99}$ concerned a building company that had become insolvent after encountering difficulties in connection with a major building contract. Some of the company's work on this and other projects had been done through a subcontracting arrangement with a related entity that had the same directors as the company (the two entities also had a common sole company shareholder, which was in turn owned by the same directors). The company shared office space with the sub-contractor, and the two entities had a joint overdraft facility. At a time when the company was already insolvent, and on the same day that the directors had contacted insolvency practitioners, the directors reviewed the company's arrangements with the sub-contractor and resolved to set-off the claims each had against the other, and pay a balance of $£ 72,225.66$ owing to the sub-contractor. Selected other subcontractors, not related to the company but also working on the company's main building project, were also paid. The liquidators contended that the directors had acted in breach of duty in embarking upon the netting exercise when they did, and in authorising the payment of the balance to the related party subcontractor. This argument succeeded. Registrar Barber found that the netting process bore "all the hallmarks of a process of "shutting up shop"” and had been "the first step in a rapid, informal liquidation" conducted by the directors. ${ }^{100}$ This "informal liquidation" had been conducted self-interestedly, with a view to maximising the possibility of the directors continuing to have some involvement in the major project after the liquidation of the company:

I have no doubt that [the directors] did wish to keep the subcontractors (including the [related party subcontractor]) on site. Given the parlous state of the company by this stage however... this was not with a view to the company finishing off the job itself. Rather, [the directors] wished to keep the sub-contractors (including the [related party subcontractor]) on site long enough for the client on the project to re-employ them. This served to preserve relations between the respondents and certain of the sub-contractors working on [the project]. The job could continue without the company. ${ }^{101}$

The judge held that the payment to the related party had been made in breach of (West Mercia affected) duty, ${ }^{102}$ and that the directors were liable to restore the $£ 72,225.66$ to the company. ${ }^{103}$ The judge also held that the payment was vulnerable to avoidance as

\footnotetext{
98 [106]; [116]; [124].

99 [2016] BCC 153.

100 ibid [76].

101 ibid [99]. One of the directors was subsequently retained by one of the unrelated subcontractor

companies.

102 Specifically, in breach of Companies Act 2006 s 172, which the judge described in the circumstances of insolvency as "a duty to act in the way he considered, in good faith, to be in the best interests of the creditors as a whole": ibid [82].

103 The order being given in West Mercia form (see above, text to n 80): [116].
} 
a preference, ${ }^{104}$ but no preference action appears to have been pursued - perhaps because the payee was (as in West Mercia) also in insolvency proceedings.

In the fourth case, Re Cosy Seal Insulation Ltd (in administration), ${ }^{105}$ the administrators alleged that a sole shareholder-director, Mr Gaffney, had acted in breach of duty in authorising various payments in the months leading up to the administration, at a time when the company was already insolvent. ${ }^{106}$ Some of the payments were made to the director himself, to discharge loans he had made to the company: these were successfully attacked as voidable preferences, ${ }^{107}$ but Behrens $\mathrm{J}$ also found that the decision to authorise them had amounted to a breach of the director's (West Mercia affected) duties. ${ }^{108}$ Another set of payments were made to a related company, the sole shareholder-director of which was Mrs Gaffney. These payments were similarly held to be voidable preferences, ${ }^{109}$ but the judge also held that in authorising them $\mathrm{Mr}$ Gaffney had acted in breach of his (West Mercia affected) duties. ${ }^{110}$ He concluded that Mr Gaffney was jointly liable with the payee related company to repay the money paid out by way of equitable compensation. ${ }^{111}$

The effect of these cases appears to be to impose liability on directors who decide, at a point where 'the end is nigh', to conduct a sort of "mini liquidation" 112 - a distribution to those creditors whose repayment would in some way benefit directors. Such payments will typically be vulnerable to avoidance as preferences: the fact pattern in the cases reviewed above involves the payment of creditors at a time when the company is already insolvent and the commencement of insolvency proceedings appears imminent (such that the 'relevant time' components of s 239 are likely satisfied) ${ }^{113}$, in circumstances where it is in the authorising director's personal interest to improve the position of the payee relative to other creditors (such that the desire element of s 239 is likely satisfied, and in cases involving connected party creditors will be presumed satisfied until the contrary is shown). ${ }^{114}$ What West Mercia offers is an alternative means of putting unsecured creditors back in the distributional position they would otherwise have been in had the payments not been made. ${ }^{115}$ Compared with bringing a preference action, the West Mercia route may be regarded as preferable by a liquidator or administrator for any number of reasons: perhaps because the director has greater resources than the payee (as where, as in West Mercia and in Micra Contracts, the payee is also insolvent), or because the series of payments can be bundled into one action against a single defendant (as in Micra Contracts and HLC), or because more than one director can be validly implicated. ${ }^{116}$

\footnotetext{
${ }^{104}$ Note 99 at [108]-[111].

105 [2016] 2 BCLC 319.

106 ibid [127], [134].

107 ibid [142]-[146].

108 ibid [166].

109 ibid [149]-[151].

110 ibid [164]-[166].

111 ibid [167].

112 The language used to object to the operation of the clearing-house arrangement in British Eagle International Airlines Ltd v Compagnie Nationale Air France [1975] 1 WLR 758, 780.

113 Above text to $n 76$.

${ }^{114}$ Above $n 77$ and accompanying text.

${ }^{115}$ Assuming that any order is made in West Mercia form: see above, text to $\mathrm{n} 80$, and (noting the apparent absence of such a proviso in Re Cityspan Ltd) n 94.

${ }^{116}$ On the other hand, from an unsecured creditor perspective one potential disadvantage of the West Mercia action relative to a preference action is that the fruits of preference and other office-holder
} 
At first glance, there does not appear to be anything startling about this use of West Mercia: once it is accepted that in insolvency and its vicinity the duties owed by directors are affected by an obligation to have proper regard to the interests of creditors "as a whole", the conduct of a 'mini-liquidation' of the kind described in HLC appears readily capable of constituting a breach of duty. As Newey J observed in GHLM Trading Ltd v Maroo: ${ }^{117}$

A director of a company has a duty to act "in the way he considers, in good faith, would be most likely to promote the success of the company for the benefit of its members as a whole" (see section 172 of the Companies Act 2006). Where creditors' interests are relevant, it will similarly, in my view, be a director's duty to have regard to the interests of the creditors as a class. If a director acts to advance the interests of a particular creditor, without believing the action to be in the interests of creditors as a class, it seems to me that he will commit a breach of duty. ${ }^{118}$

On closer inspection, however, there is a fundamental difficulty with applying West Mercia in this way, and this lies in the relationship between the cause of action on which West Mercia depends - a breach of duty owed to the company - and the remedy for breach. Although some aspects of the rule are ambiguous, it is at least clear that it operates by altering the duties that directors owe to the company, rather than by supplying any new duty owed to creditors. ${ }^{119}$ Once this is accepted, then the case for awarding any compensatory remedy appears doubtful. From the perspective of the insolvent company's unpaid creditors, the payment of one creditor produces a loss: they are forced to share pro rata in the remaining assets, while the payee recovers in full. But from the perspective of the company, to which West Mercia affected duties are owed, there is no loss at all. Keay has contended otherwise, noting that some of the West Mercia cases appear to equate the company with the creditors when describing the rule's effect, ${ }^{120}$ and arguing that this suggests that the relevant loss is the creditors'. ${ }^{121}$ But this cannot be right: it is well established that West Mercia affects only duties owed to the company, and that a breach of West Mercia affected duty is actionable only by, or in right of, the company. ${ }^{122}$ The only relevant loss can be that of the company itself. ${ }^{123}$ It is true that the court in Kinsela described the assets of the insolvent company as those of its creditors, but only "in a practical sense" on the basis of creditors' ability to restrain directors and shareholders from dealing with company assets "through the mechanism of liquidation"; ${ }^{124}$ nothing in this changes the basic

actions are not susceptible to capture by a chargee (above, $\mathrm{n}$ 79), while the fruits of a West Mercia action (as one brought in right of the company, for breach of duty owed to the company) are so susceptible: Re Oasis Merchandising Services Ltd [1998] Ch 170, 181 and below n 150.

117 [2012] 2 BCLC 369.

118 ibid [168].

119 See above text to $\mathrm{n} 3$ and $\mathrm{n} 29$.

${ }^{120}$ See e.g. $\mathrm{n} 102$ above. $C f$ the description of the rule by Lords Toulson and Hodge in Bilta $v$ Nazir (n

1) [126]-[127], noted below, n 125.

${ }^{121}$ Keay LQR (n 33) 466-469.

122 See $n 11$ above.

${ }^{123}$ This does not mean, of course, that the authorisation of a preference cannot constitute a breach of duty, as Newey J made clear in GHLM v Maroo (text to n 118): the problem arises at the remedial stage, if the remedy is to be a compensatory one.

${ }^{124}$ See above, text to n 25 (emphasis added). 
position that the company is distinct from its creditors in the same way that it is distinct from its shareholders, and that it is to the company that West Mercia affected duties are owed. ${ }^{125}$ As Park J reasoned in Singer v Beckett:

This misfeasance claim by the liquidators is a claim for breach of the common law duty which directors owe to the company, not a claim for breach of any duty which they owe directly to the creditors of the company, still less of any duty owed to some creditors but not to others. Because the duty is owed to the company, any loss, if it is going to be recoverable by way of an action for misfeasance, must be loss suffered by the company. However, the payment by [the company] of its liabilities... did not cause any loss to [the company]. It may have caused loss to the creditors other than [those who were paid], but it did not cause any loss to the company... the discharge by a company of a liability to which it is already subject does not cause it any loss. ${ }^{126}$

In GHLM Trading Ltd v Maroo, Newey $\mathrm{J}$ reached a similar conclusion on the availability of a compensatory remedy, ${ }^{127}$ but noted that in cases where directors had profited from a preference in breach of (fiduciary) ${ }^{128}$ duty they would be liable to account for this (i.e. a gain-based remedy would be available). ${ }^{129}$ As the judge acknowledged, however, it may sometimes be difficult to determine the extent to which a director has profited from a preference. ${ }^{130}$

Other cases suggest an alternative approach to this remedial question might be available where directors authorise payments to creditors self-interestedly or otherwise in breach of a fiduciary duty. ${ }^{131}$ In HLC Environmental Projects, ${ }^{132}$ deputy judge John Randall QC rejected an argument that the liability of the director who had self-interestedly authorised payments to creditors in breach of duty was limited to disgorgement of any profits obtained by the director and compensation for any loss suffered by the company. The judge held that the director could be liable to restore to the company the amounts

\footnotetext{
${ }^{125}$ Consistently with this analysis, Lords Toulson and Hodge in Bilta v Nazir (n 1) described an action for breach of West Mercia affected duty as one "brought by the liquidators in the name of the company to recover, for the benefit of the creditors, the loss caused to the company by the directors' breach of their fiduciary duty” ([127], emphasis added).

${ }^{126}$ [2007] 2 BCLC 287, [419].

${ }^{127}$ Note 117 at [169].

128 The judge identifying such fiduciary duties to include the duty to act in good faith to promote the success of the company (ibid [193]), consistently with Sinclair Investments (UK) Ltd v Versailles Trade Finance Ltd [2012] Ch 423, [36] and, in Australia, the Western Australian Court of Appeal in Westpac v Bell [2012] WASCA 157; 89 ACSR 1, [909]-[923], [1978], [2733]. cf the Hong Kong decision in Moulin Global Eyecare Holdings Ltd (in liquidation) v Olivia Lee Sin Mei [2014] HKCFA 63, (2014) 17 HKFCAR 266, [35]-[36], [37].

${ }^{129}$ Newey J also identified another route to a remedy, this time from the payee. The judge held that where a director acts in their own interests in authorising a payment ("rather than those of the company, its members or (where appropriate) its creditors as a class"), and the recipient knows of the breach, the transaction may be void. This analysis will be important where a liquidator/administrator seeks a remedy against a creditor who received a payment that cannot be unwound as a preference (an alternative approach would be to pursue the creditor using accessory liability rules: see Section 5 below), or where, as in GHLM v Maroo itself, the company is not in insolvency proceedings at all. 130 Note 117 at [169].

${ }^{131}$ Such fiduciary duties including not only proscriptive duties concerning the avoidance of conflicts, the making of unauthorised profits, and self-dealing, but also the duty to act in good faith to promote the success of the company: ibid n 128.

132 [2014] BCC 337.
} 
paid out to the creditors, in the same way that he understood that a trustee who misapplied trust assets could be liable to restore the assets or their value to the trust fund: "The liability of a defaulting fiduciary who has, by his or her default, allowed the trust fund to become denuded is, or includes, a liability to restore the fund to what it should have been". ${ }^{133}$

Two points can be made in response to this. First, although the judge did not say so, the drawing of any analogy between remedies available against a defaulting trustee and those available against a defaulting director should presumably be confined to cases in which the director defaults in his or her fiduciary duties: the analogy appears inappropriate in cases involving only breaches of non-fiduciary duty. ${ }^{134}$ There will, however, be no difficulty in establishing a breach of fiduciary duty in cases where a director authorises payments to creditors for her own ends: acting self-interestedly will place the director in breach of her proscriptive duties, ${ }^{135}$ and the breach will be incapable of ratification or authorisation by the company in insolvency or its vicinity. ${ }^{136}$ It is perhaps for this reason that Dillon LJ saw no difficulty in ordering the director in West Mercia to pay to the company that which had been paid out to the parent, without reference to either compensation of (company) loss or disgorgement of (director) gain:

Prima facie the relief to be granted where money of the company has been misapplied by a director for his own ends is an order that he repay that money with interest, as in Re Washington Diamond Co. ${ }^{137}$

The second point about the restorative remedial analysis is more difficult. HLC Environmental Projects was decided in 2013. In 2014, the Supreme Court handed down its decision in AIB Group (UK) plc v Mark Redler. ${ }^{138}$ In issue in AIB was whether a trustee could be ordered to reconstitute a trust fund by repaying that which had been wrongly paid out from the fund in circumstances where (almost all of) the loss caused to the beneficiary would have been suffered even if the breach had not occurred. The Supreme Court held not, Lord Toulson reasoning:

[A]bsent fraud, which might give rise to other public policy considerations that are not present in this case, it would not in my opinion be right to impose or maintain a rule that gives redress to a

\footnotetext{
133 ibid [142].

134 e.g. the duty to exercise reasonable care, skill and diligence (Companies Act 2006 s 174), conventionally characterised as non-fiduciary: R.C. Nolan, 'Controlling Fiduciary Power' (2009) 68(2) CLJ 293, 309; Gower (n 11) [16-37]. Interestingly, the judge in HLC did not appear to draw the same distinction between breaches of fiduciary and non-fiduciary duty in confirming the availability of the restorative remedy: (n 132) at [134]-[145]. In Moulin Global Eyecare Holdings (n 128) the Hong Kong Court of Final Appeal relied on this aspect of $H L C$ to reach the conclusion that a claim that a director was liable to restore money paid out in breach of the duty to act bona fide in the best interests of the company was reasonably arguable, notwithstanding that Court's view that this was an equitable non-fiduciary duty.

135 i.e. those concerning the avoidance of conflicts, the making of unauthorised profits, and selfdealing.

136 Text to n 32.

137 (1988) 4 BCC 30, 33. In issue in Re Washington Diamond Co [1893] 3 Ch 95 was whether payments made to two directors by way of cheques signed by the same two directors were fraudulent preferences within the meaning of s 164 Companies Act 1862. At first instance Vaughan Williams J held not, but this finding was overturned on appeal. Lindley LJ, with whom Bowen LJ agreed, held that the two directors were jointly and severally liable to repay the amounts paid out. Kay LJ would have gone further: "I think that all the directors who concurred in making the payments were guilty of a misfeasance, and that the order should direct them jointly and severally to repay the amounts" (115). 138 [2015] AC 1503.
} 
beneficiary for loss which would have been suffered if the trustee had properly performed its duties. ${ }^{139}$

The remedial difficulty in the West Mercia cases is not that the loss complained of would have been suffered anyway, but that the director's breach caused no loss to the company at all. The compensatory focus of the reasoning in $A I B^{140}$ might, though, be thought to cast doubt on the validity of any restorative order made by analogy with the accounting responsibility of a defaulting trustee in circumstances where the breach causes no loss. There is at least one argument that could be marshalled to resist this conclusion: Lord Toulson expressly reserved his position on cases involving fraud. ${ }^{141}$ The self-interested conduct of a 'mini liquidation' in the lead-up to insolvency proceedings appears fairly characterised as fraudulent; it could certainly be described as a species of 'fraud on the creditors'. ${ }^{142}$ This could potentially warrant a more generous approach to the availability of the restorative remedy.

Are there other routes to a remedy against directors who authorise the payment of preferences to others for their own ends? The provisions of the Insolvency Act 1986 might themselves be thought to provide a remedy, for s 241(1)(d) provides that where a preference has been established under s 239, the court may in making an order to restore the company to the pre-transaction position "require any person to pay, in respect of benefits received by him from the company, such sums to the office-holder as the court may direct". It has been held, however, that this should not be used to order payment by a director who benefits only indirectly from a preference. In Oxford Pharmaceuticals Ltd, Wilson v. Masters International Ltd, the liquidator argued that a director who benefited from payment of a preference to a related entity, of which he was a shareholder and for which he was guarantor, should be ordered to repay the amount paid out under s 241. The judge held that such an order would be inappropriate, restricting the section to cases where third parties were "in possession of assets applied in making the preference or, at least, had otherwise personally benefited in monetary terms from the payment in some direct and tangible way". ${ }^{143}$

The reform of the Company Directors Disqualification Act 1986 ('CDDA') does, however, provide another route to a remedy. Section 15A of the CDDA, inserted by the Small Business, Enterprise and Employment Act 2015, now provides for directors to be made (on the application of the Secretary of State) subject to "compensation

\footnotetext{
139 ibid [62]. Lord Neuberger, Lady Hale and Lord Wilson agreed with the judgment of Toulson LJ and the judgment of Lord Reed, the latter describing his reasons as "substantially the same as those of Lord Toulson” ([78]).

${ }^{140}$ PS Davies, 'Remedies for Breach of Trust' (2015) 78(4) MLR 672, 693. As to whether the result in $A I B$ can be explained on the basis of the traditional understanding of the process of accounting, compare M Conaglen, ‘Equitable compensation for Breach of Trust: Off Target” [2016] MelbULawRw 11, with R.C. Nolan, 'Invoking the Administrative Jurisdiction: The Enforcement of Modern Trust Structures' in Paul Davies and James Penner (eds) Equity, Trusts and Commerce (Hart 2017).

${ }^{141}$ A further argument may be that the context of AIB (not a directors' duty case) is far removed from that in issue in the West Mercia case law. The difficulty, however, is that the restorative remedial analysis does appear to depend on the drawing of an analogy between the position of the defaulting director and that of a defaulting trustee: above, text to $\mathrm{n} 133$.

142 J Armour, 'Avoidance of Transactions as a 'Fraud on Creditors' at Common Law' in J Armour and H Bennett, Vulnerable Transactions in Corporate Insolvency (Hart 2003) [7.5], [7.103].

143 [2010] BCC 834, [84]. The judge had earlier concluded that the authorisation of the preferences had not amounted to a breach of duty by the director: ibid $n 91$.
} 
orders" 144 in circumstances where they have been disqualified under the CDDA, and the conduct for which they were disqualified "caused loss to one or more creditors of an insolvent company of which the person has at any time been a director". ${ }^{145}$ An "insolvent company" is one that has entered balance-sheet insolvent liquidation, or administration. ${ }^{146}$ Where these conditions are satisfied, the court may make an order requiring an amount be paid over to the Secretary of State for the benefit of a creditor or creditors or class or classes of creditor, or to the company (s 15B(1)). In setting the amount, the court is required to have regard to "the amount of loss caused" (presumably a reference to the loss caused "to one or more creditors" that enlivens the court's jurisdiction to make the order), the nature of the conduct, and whether the person has "made any other financial contribution in recompense for the conduct" (s 15B(3)).

The authorisation of a voidable preference does not necessarily constitute a breach of duty, ${ }^{147}$ and it appears doubtful whether mere authorisation of a preference (without a finding that this was given in breach of duty) would without more render a director liable to be disqualified. ${ }^{148}$ Where, however, the authorisation does constitute a breach of duty, this would appear to be grounds for disqualification, ${ }^{149}$ and disqualification would expose the director to the risk of liability under the new compensation regime. Two features of this regime are particularly noteworthy. The first is that the focus in section 15A is on loss caused "to one or more creditors", rather than on loss caused to the company. This means that there should be no difficulty in obtaining compensation in cases where the conduct for which a director was disqualified caused loss to one or more creditors but no loss to the company, as where preferences have been paid. The second feature is that the court has discretion in relation to the question of to whom compensation is payable. Section 15B provides that the court may order payment to the Secretary of State for the benefit of select creditors or classes of creditor, or to the company. This suggests that it might be possible to make compensation payable to those who were creditors at the time of the relevant conduct, excluding those who became creditors later. No such order could be made in relation to remedies for breach of West Mercia affected duties: those duties are owed to the company, and recoveries for breach will accrue for the benefit of the company. ${ }^{150}$

These features suggest that the application of the CDDA regime to cases involving the payment of preferences might produce different remedial results to that which could be obtained by a misfeasance action. This means that some creditors may still want officeholders to pursue misfeasance actions, even where there are strong prospects of the Secretary of State pursuing disqualification and a related compensation order. Other creditors may however not favour such actions, for example because they expect their position to be adequately protected by a CDDA compensation order, such that the

\footnotetext{
144 The Secretary of State may accept a compensation undertaking from a director so as to avoid the need for a compensation order: CDDA s 1A, 15A(2).

145 s $15 \mathrm{~A}(3)$.

${ }^{146}$ Or in respect of which an administrative receiver has been appointed: $15 A(4)$.

${ }^{147}$ GHLM Trading Limited v Maroo (n 117) [168], citing Re Brian D Pierson (Contractors) Ltd [2001]

1 BCLC 275, 299 (extracted above, text to n 91).

${ }^{148}$ Consistently with this, see Insolvency Service, Company Directors Disqualification Act 1986:

Guidance Notes for the Completion of Statutory Reports and Returns, Department of Business, Innovation and Skills, 27.

${ }^{149}$ Westminster Property Management (n 32) [72]-[74].

150 They are therefore susceptible to capture by a secured creditor whose security extends to afteracquired property. Sections 15A-B of the CDDA are silent on this point.
} 
pursuit of a misfeasance action will involve (from their perspective) the incurring of unnecessary expenses that diminish the estate available for distribution. ${ }^{151}$ This will be a complex position for an office-holder to navigate.

\section{Exploring the Reach of the Rule: Lessons from Westpac $v$ Bell}

Westpac Banking Corporation v Bell Group Ltd ${ }^{152}$ was one of the longest running cases in Australian history. Like West Mercia Safetywear, Westpac v Bell concerned transactions with company creditors in the lead-up to the commencement of insolvency proceedings. It arose out of the collapse of the Bell Group in the early 1990s. The Group had funded its expansion by unsecured bank borrowing and the issue of subordinated convertible bonds to (primarily foreign) investors. The proceeds of bond issues by one special purpose vehicle subsidiary were on-lent to two other companies in the Group, and those borrower companies were also indebted to the banks. Although the banks sought to contend otherwise, the on-loans were not made on a subordinated basis, ${ }^{153}$ with the result that in an insolvent liquidation of those companies the banks would have had to compete on a pari passu basis with the subsidiary lender in relation to the on-lent proceeds of the bond issues. ${ }^{154}$ When the viability of the Bell Group was thrown into doubt in the late 1980s, the banks became aware of their position. ${ }^{155} \mathrm{~A}$ "refinancing" "156 was then negotiated between the Bell Group companies and the banks. Its effect was to dramatically improve the position of the banks relative to other creditors: intra-group debt (including the loan of bond proceeds) was subordinated, and unsecured bank debt was converted to secured debt through the grant of security interests in available assets, supported by guarantees. ${ }^{157}$ By the time that the companies entered liquidation, the banks had made substantial recoveries, and had the benefit of security interests and guarantees in relation to outstanding claims. In other words, as Lee AJA put it in the Court of Appeal, there had already been an "informal administration”, conducted for the benefit of the banks. ${ }^{158}$

The benefits accruing to the banks as a result of the refinancing were clearly factual preferences, made at a time when the relevant companies were already insolvent. They were not, however, vulnerable to avoidance by the liquidators under the applicable

\footnotetext{
${ }^{151}$ Some investigatory expenses will be incurred by the office-holder in connection with the disqualification regime, for liquidators and administrators are required to report to the Secretary of State on the conduct of directors to assist the Secretary in determining whether to pursue disqualification: CDDA 1986 s7A. In the case of misfeasance actions, the liquidator or administrator will also incur expenses in case preparation. On the non-recoverability of these expenses from the director defendant, see Grant v Ralls [2016] 1 WLR 5190.

152 Westpac Banking Corporation v Bell Group Ltd (in liq) (No 3) [2012] WASCA 157; (2012) 89

ACSR 1, on appeal from the decision of Mr Justice Owen at first instance Westpac Banking Corporation v Bell Group Ltd (in liq) (No 9) [2008] WASC 239; (2008) 70 ACSR 1.

${ }^{153}$ At first instance, Owen $\mathrm{J}$ found that the bond proceeds had been on-lent on a subordinated basis, but this finding was overturned by a majority on appeal (Carr AJA dissenting).

154 [2012] WASCA 157; 89 ACSR 1, [553].

155 ibid [549]-[555]; see also [2092].

156 No new finance was extended under the scheme. Brief extensions in the repayment of some facilities were given, but in the Court of Appeal Lee AJA found that these operated to the benefit of the banks, not the debtors: ibid [600]-[605]. He affirmed the finding of Owen J that the extension of time could not have been said to have afforded an opportunity to restructure: [607]; see similarly

Drummond AJA [2076].

157 ibid [555].

158 ibid [601].
} 
(Australian) preference rules, ${ }^{159}$ for the reason that they had been entered into outside the six-month 'suspect period' during which preferences could be impugned. ${ }^{160}$ The refinancing led to an extension of time for repayment of the bank facilities, and this (coupled with a decision by the banks to permit the release of some assets to pay interest on bonds) appears to have delayed the entry of the companies into liquidation. By the time insolvency proceedings had been commenced, the relevant transactions fell outside the statutory preference rules. The banks were aware of this; indeed the "hardening" of security interests after the expiration of the preference period was marked with a "six month celebratory lunch" organised by lawyers to one of the lead banks. ${ }^{161}$ In the Court of Appeal, Lee AJA found that the banks' consent to the maturity extension and the release of assets to pay interest on the bonds had been given for the purpose of enabling the survival of the companies beyond the 'suspect period', so as to improve the prospects of this "hardening" occurring. ${ }^{162}$

Faced with the limitations of the statutory preference rule, the liquidators pursued an alternative route to recovery from the banks. They argued that the directors of the Bell Group companies had acted in breach of their fiduciary duties, as affected by the Australian equivalent to West Mercia, in committing the companies to the refinancing, and that the banks were liable under both limbs of Barnes $v$ Addy ${ }^{163}$ - as knowing recipients of company property, and as dishonest accessories to the disposal of that property in breach of duty - to disgorge the benefits they had received. At first instance, Owen $\mathrm{J}$ found that various directors had acted in breach of (creditor-regarding) fiduciary duties, and that the banks were liable under the first (knowing receipt) limb of Barnes $v$ Addy. On appeal, a majority of judges in the Court of Appeal affirmed (and indeed extended) ${ }^{164}$ the findings of breach of (creditor-regarding) fiduciary duties, ${ }^{165}$ and held that the banks were liable under both limbs of Barnes $v$ Addy. The banks obtained special leave to appeal to the High Court, but the case subsequently settled reportedly leading to a payment by 20 banks of a sum of AU\$718 million to the liquidators.

It was not suggested that the directors of the Bell Group companies personally benefited from the refinancing. ${ }^{166}$ In this respect, Westpac v Bell is very different to West Mercia. It suggests that there is scope for West Mercia to play a role not only in cases where a 'mini liquidation' is conducted by a director acting self-interestedly, but also (when combined with accessory liability rules) in cases where directors agree to such a scheme at the behest of dominant creditors. If the director's agreement is given in breach of

\footnotetext{
159 Some other avoidance rules were found to be applicable. The remedial implications of this were not, however, fully explored, for the reason that Owen J found it unnecessary to do so, having found for the liquidators on an alternative basis (breach of directors' duties, coupled with accessory liability for the banks): ibid [711]-[712].

160 [2008] WASC 239; (2008) 70 ACSR 1, [9066].

161 [2008] WASC 239; (2008) 70 ACSR 1, [542].

162 [2012] WASCA 157; 89 ACSR 1, [602], and [2359]-[2362].

163 (1874) LR 9 Ch App 244.

${ }^{164}$ By finding that Owen $\mathrm{J}$ had been wrong to hold that a director of the subsidiary that on-lent the bond proceeds had not acted in breach of duty when committing the company to the subordination arrangements in the refinancing: [2012] WASCA 157; 89 ACSR 1, [2434].

165 ibid per Lee AJA, [918]-[933] (due to act bona fide in the interests of the company; duty to exercise powers for proper purposes), the breach analysis at [942]-[1019] and [1047]-[1068], and the summary at [1086]-[1093]; Drummond AJA, [2013]-[2051] (the creditor-oriented duty-shifting rule) and then [2079] (agreeing with Lee AJA’s reasons on breach). Carr AJA dissented.

166 ibid [1943], [2722].
} 
fiduciary duty, ${ }^{167}$ then any creditor who dishonestly assists in the breach could be liable to disgorge their gains under the English accessory liability rule. ${ }^{168}$ Importantly, this use of West Mercia raises no remedial difficulty: the defendant is the creditor who benefited from the mini-liquidation, and the remedy is a restitutionary one - the disgorgement of benefits received. Having returned these benefits, the creditor would be entitled to submit a proof in the company's liquidation; indeed, the banks in Westpac $v$ Bell were held to be so entitled on disgorging their gains. ${ }^{169}$ The overall result is similar to the reversal of a preference using transaction avoidance rules. Of course, the general law substitute will only be available in cases where the elements of dishonest assistance are made out. This may be a narrow category of case, ${ }^{170}$ but its availability may nevertheless be important, given the possibility that dominant creditors may be able to anticipate the limitations of statutory avoidance rules, and structure their arrangements with the company accordingly.

\section{Conclusion}

The West Mercia Safetywear rule is conventionally analysed as one that resolves (in creditors' favour) an anticipated conflict between creditors and shareholders over the appropriate level of risk to be taken in the deployment of company assets in the vicinity of insolvency. On this analysis, West Mercia substantially overlaps with the wrongful trading rule in the Insolvency Act 1986, but is usefully capable of being triggered earlier. Both rules would enable a liquidator or administrator to seek compensation from a director who deployed assets in a 'high-risk, high-reward' investment strategy that failed.

A review of the West Mercia case law suggests that the rule has acquired a second function, not able to be performed by the wrongful trading rule: the regulation of distributions to creditors in the lead-up to insolvency proceedings. On this analysis, the rule overlaps with the preference rule in s 239 of the Insolvency Act 1986, providing another route to a remedy for creditors aggrieved by a director's decision to conduct a 'mini-liquidation'. On its own, West Mercia has been used to require directors who have self-interestedly conducted such a 'mini-liquidation' to return to the company that which was paid out to creditors, the (apparently restorative) ${ }^{171}$ remedy being tailored to place unsecured creditors in a similar position to that which they would have been in had the payments been unwound as preferences. Whether this application of West Mercia can survive the decision of the Supreme Court in AIB Group (UK) plc v Mark Redler $^{172}$ is an open question, but it is certainly arguable that it can, given that the Court expressly reserved its position on fraud. West Mercia can however also be used in

\footnotetext{
${ }^{167}$ A breach of fiduciary duty appears necessary to render the dishonest assistant liable to account for profits in circumstances where the assistant is not themselves in a fiduciary relationship with the claimant: Novoship (UK) Limited \& Ors v Mikhaylyuk and ors [2015] QB 499, [68]-[84].

168 Liability for knowing receipt under English law seems less likely, for the reason that the knowing receipt rule appears to require receipt of trust property: Novoship ibid [89]-93].

169 [2012] WASCA 157; 89 ACSR 1, [1148], [1129].

170 Particularly because a creditor may be so dominant that they risk characterisation as a shadow director, which would expose them to direct liability for breach of directors' duties. But in cases falling short of shadow directorship, accessory liability may have a role to play.

${ }^{171}$ It would be possible to recharacterise the remedy ordered in some of the cases reviewed in Section 4 as gain-based (i.e. an account of profits), but this recharacterisation will not be available where the director's gain would not be expected to perfectly correspond with the amount received by the creditor. 172 Note 138.
} 
another way: in combination with rules of accessory liability, so as to require a payee creditor who has (dishonestly) assisted with the conduct of a 'mini-liquidation' to disgorge the benefits obtained from doing so. There is no remedial difficulty with this application of the rule, and its availability may be important in cases where dominant creditors are able to anticipate and strategically avoid the application of preference rules.

Are there any problems with embracing West Mercia's distributional function? Is there, for example, a risk that the spectre of personal liability for directors who authorise payments to creditors in the vicinity of insolvency might cause directors to prefer early closure to continued trading, even where trading would reasonably be expected to benefit creditors? Is there a risk that the shadow of accessory liability will deter dominant creditors from participation in genuine restructuring negotiations? The latter concern can be readily dismissed, for accessory liability requires dishonesty: there is liability only for dishonest assistance in a breach of fiduciary duty. As to the liability of directors themselves, no dishonesty is required to establish a breach of a West Mercia affected duty. The remedies that may be obtained from a defaulting director are, however, limited. There can be no order to compensate the company for breaches in authorising preferences, since these cause the company no loss. A director may be ordered to disgorge gains, but this will require evidence of profits derived from breach of a fiduciary duty. A director who acts in what they honestly believe to be the interests of creditors, having considered these, ${ }^{173}$ and who does not act self-interestedly, will likely satisfy their fiduciary duties. The prospect of the third form of remedy suggested by the cases - an order to restore that which has been paid out, without evidence of either company loss or director profit - is also limited. At minimum, such a restorative remedy ought to be confined to cases involving breach of fiduciary duty; ${ }^{174}$ moreover, the effect of $A I B^{175}$ may be to confine this remedy to cases where the director's conduct can properly be characterised as fraudulent. By contrast, the new compensation regime in the Company Directors Disqualification Act 1986 is considerably wider, and as such may be more likely to have an adverse effect on the conduct of directors in insolvency and its vicinity.

\footnotetext{
173 Section 172 (the duty to act in good faith to promote the success of the company, the successor to the duty to act bona fide in the interests of the company) is primarily subjective, provided that "there is evidence of actual consideration" of the relevant interests: see Re HLC Environmental Projects Ltd (n 132) [92(b)].

174 Text to 134.

${ }^{175}$ Assuming it is treated as applicable in the West Mercia context: above, n 141.
} 